\title{
Using in silico viral kinetic models to guide therapeutic strategies during a pandemic: An example in SARS-CoV-2
}

\author{
Kashyap Patel ${ }^{1}$, Michael Dodds ${ }^{2}$, Antonio Goncalves ${ }^{3}$, Mohamed Kamal $^{4}$, Craig Rayner $^{2}$, \\ Carl Kirkpatrick (NO NEW ASSIGNMENTS) ${ }^{5}$, and Patrick Smith ${ }^{2}$ \\ ${ }^{1}$ Certara \\ ${ }^{2}$ Certara LP \\ ${ }^{3}$ INSERM \\ ${ }^{4}$ Roche Innovation Center \\ ${ }^{5}$ Monash University
}

September 10, 2020

\begin{abstract}
AIM: We propose the use of in silico mathematical models to provide insights that optimize therapeutic interventions designed to eradicate respiratory infection during a pandemic. A modelling and simulation framework is provided using SARS-CoV-2 as an example, considering applications of both treatment and prophylaxis. METHODS: A target cell-limited model was used to quantify the viral infection dynamics of SARS-CoV-2 in a pooled population of 105 infected patients. Parameter estimates from the resulting model were used to simulate and compare the impact of various interventions against meaningful viral load endpoints. RESULTS: Robust parameter estimates were obtained for the basic reproduction number, viral release rate and infected-cell mortality from the infection model. These estimates were informed by the largest dataset currently available for SARS-CoV-2 viral time course. The utility of this model was demonstrated using simulations, which hypothetically introduced inhibitory or stimulatory drug mechanisms at various target sites within the viral life-cycle. We show that early intervention is crucial to achieving therapeutic benefit when monotherapy is administered. In contrast, combination regimens of two or three drugs may provide improved outcomes if treatment is initiated late. The latter is relevant to SARS-CoV-2, where the period between infection and symptom onset is relatively long. CONCLUSIONS: The use of in silico models can provide viral load predictions that can rationalize therapeutic strategies against an emerging viral pathogen.
\end{abstract}

\section{What is already known about this subject}

- To date, quantification of SARS-CoV-2 viral kinetics have utilized clinical data from very small numbers of patients;

- Viral kinetic models have been shown to be useful in other viral diseases.

\section{What THIS STUDY ADDS}

- This study uses the largest available viral load dataset to provide robust estimates that inform key parameters of SARS-CoV-2 infection;

- Model estimates provide information on the dose potency required for inhibition or stimulation of target sites within the viral life-cycle;

- Our approach is applicable to current and future pandemics. 


\section{Introduction}

As the COVID-19 pandemic entered the world in late 2019 and early 2020, little information was available regarding potential therapeutic strategies to address this emerging pathogen. Several key questions emerged that focused on pre-existing antivirals, with consideration of the optimal dose, time to initiate treatment or prophylaxis, and the possibility of selecting combination regimens ${ }^{1-5}$. While some of these questions have been partially answered, most remain open, as we approach one year after initiation of the global pandemic.

The use of in silico modelling and simulation has proven its merits as a key tool in developing novel therapies that are more effective than existing therapeutics ${ }^{6-8}$. These models are particularly useful to inform decision making in areas where clinical trials are unavailable or not feasible, and has been applicable to the COVID-19 global pandemic. The use of mathematical models which characterize viral dynamics can provide critical insights early in a pandemic, to address some of the key questions outlined above. These understandings are useful to guide treatment sites within the virus life-cycle. Establishing and applying robust viral kinetic (VK) models is therefore a critically important foundation to support strategies for optimising therapeutic interventions. These models can additionally serve to extrapolate unknown components of the VK curve (e.g. time of infection to symptom onset), or for linking infectiousness to transmissibility in epidemiological analyses ${ }^{9}$.

SARS-CoV-2 establishes an infection by binding to angiotensin-converting enzyme 2 (ACE2) receptors on surface epithelial cells in the upper respiratory tract ${ }^{10}$. While this process is similar to that for other respiratory viral infections, the incubation time of SARS-CoV-2 approximates 6 to 13 days ${ }^{11,12}$, and is longer than influenza ( $>48$ hours) ${ }^{13}$. As a consequence, symptom onset and corresponding diagnosis is longer [range 5-24 days] ${ }^{14}$ following SARS-CoV-2 infection, and may occur just prior to or at the time of maximal virus. Furthermore, the duration of viral shedding is $2-3$-fold longer for SARS-CoV-2 (21 - 30 days) ${ }^{15}$, compared to influenza ${ }^{16,17}$ or Respiratory Syncytial Virus (RSV) ${ }^{18}$.

Target cell-limited models that characterize the in-host infection dynamics of influenza ${ }^{16,17}$ and RSV $^{19,20}$ are well established, and have been applied to SARS-CoV-2. Integrating the pharmacokinetics (PK) and pharmacodynamics (PD) of re-purposed drugs into the virus life-cycle using in silico modelling may therefore better rationalize appropriate treatment strategies ${ }^{1,2,21}$. In this manuscript, we sought to use a nonlinear mixed effects modelling approach to develop a target cell-limited model for SARS-CoV-2 using pooled data from published studies. A large dataset of viral load time course was generated from more than 100 subjects, to construct a robust foundation that describes the infection dynamics of SARS-CoV-2.

We aimed to utilize this model to perform Monte Carlo simulations that visualize viral pre-exposure prophylaxis, post-exposure prophylaxis and treatment profiles for a range of dosing scenarios. Specifically, we wanted to focus on i) the selection of single agent or combination therapy; ii) identifying the dose potency; and iii) the timing of dose initiation required to achieve success. We use this approach to suggest a generalized framework that may guide optimized prophylactic or treatment strategies for SARS-CoV-2 and future pandemics.

\section{Materials and Methods}

\section{Viral Kinetic Data}

Nasopharyngeal, nasal-throat swab, or oropharyngeal viral load data sampled from the upper respiratory tract were digitized from 13 published studies $\left(\mathrm{N}=105\right.$ infected symptomatic patients) ${ }^{13,22-34}$. Viral load measurements reported as cycle threshold $(\mathrm{Ct})$ values were converted to $\log _{10}$ copies/mL, using the standard curve provided by Zou et al ${ }^{32}$. The lower limit of quantitation (LLOQ) was defined as indicated within each study. A summary of the data is provided in Table $\mathbf{1}$, and include stratification of the number of subjects ( $\mathrm{N}=36$ total; $34 \%$ of pooled dataset) that received some form of treatment. Inter-study comparison of the observed viral load area under the curve (AUC) between untreated and treatment arms identified no significant difference between the two groups (Table 1 ). We therefore assumed that the VK in treatment subjects were comparable to untreated, and did not include antiviral inhibition during model estimation. A 
display of the VK profiles for all data and stratified by study are shown inFigure 1 .

Target Cell-limited Model

The time course of SARS-CoV-2 in infected patients was developed using an established target cell-limited model that represents the pathophysiology of a typical viral life-cycle ${ }^{16,17}$. This model comprises three cell populations, which include susceptible target epithelial cells $(T)$ in the upper respiratory tract, nonproductive infected cells $\left(I_{1}\right)$ and infected cells $\left(I_{2}\right)$ that actively produce free virus $(V)$. The ordinary differential equations describing this system were described by Equation 1:

$$
\frac{\mathrm{dT}}{\mathrm{dt}}=-\beta T V
$$

$\frac{d I_{1}}{\mathrm{dt}}=\beta T V-k I_{1}(1)$

$\frac{d I_{2}}{\mathrm{dt}}=k I_{1}-\delta I_{2}$

$\frac{\mathrm{dV}}{\mathrm{dt}}=\rho I_{2}-c V-\beta T V$

Where $\beta$ is the second order rate constant for susceptible target cell infection by free virus $(V) ; k$ is the transition rate from non-productive cells to those actively producing virus; $\delta$ is the infected cell mortality rate; $\rho$ is the free virus production (release) rate, and $c$ is the corresponding elimination rate constant. A schematic of the target cell-limited model is provided inFigure 2 . In this model, the basic reproduction number $\left(R_{0}\right)$ represents the average number of secondary infections generated from each primary infected cell, and is given by Equation 2:

$R_{0}=\frac{\rho \beta T_{0}}{\delta\left(c+\beta T_{0}\right)}$

Several assumptions were made to avoid parameter non-identifiability, because only viral load measurement was available for model development. Based on known physiology, the number of target epithelial cells in the upper respiratory tract was assumed to be $4 \times 10^{8}$ cells homogeneously distributed in a $30 \mathrm{~mL}$ volume 16. Of these, approximately $1 \%$ are susceptible and express the ACE2 receptor and other proteases required for SARS-CoV-2 entry ${ }^{35}$. The initial concentration of target epithelial cells $\left(T_{0}\right)$ was therefore assumed to be $1.33 \times 10^{5}$ cells $/ \mathrm{mL}$. $\mathrm{V}_{0}$ was initialized at 10 copies $/ \mathrm{mL}$, with $c$ assumed to be fast based on known acute infection ${ }^{36}$, and was fixed to $10 \mathrm{~d}^{-1}$. The transition rate, $\mathrm{k}$, was fixed to $3 \mathrm{~d}^{-1}$, and reflects initiation of virus production at 8 hours after infection ${ }^{37}$. In this model, the time of infection was assumed to be five days relative to the onset of clinical symptoms ${ }^{38}$. This assumption was required to initialize infection, which is not known in patients naturally infected by the virus. Estimated fixed effects included $R_{0}, \rho$ and $\delta$. Since $R_{0}$ was estimated, the infectivity rate $\beta$ was derived by re-arranging the expression provided in Equation 2.

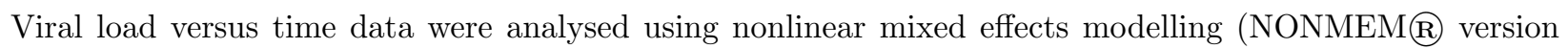
7.3.0; ICON Development Solutions, USA). The data were fitted using stochastic approximation expectation maximization (SAEM), and then by Importance sampling (IMP). Viral load was fitted using an untransformed scale, followed by logarithmic transformation to compare predictions with observed data. The between-subject variability (BSV) was modelled using an exponential variance model. Viral load observations reported as below the limit of quantitation (BLQ) were analysed using an established (M3) method for handling censored data ${ }^{39}$.

\section{Antiviral Treatment Simulations}

Target cell infectivity $(\beta)$ and free virion release $(\rho)$ mechanisms were inhibited by an intervention, while infected cell elimination $(\delta)$ and virus clearance $(c)$ were stimulated. As such, care was taken to simulate equivalent levels of intervention across these different intervention types using Equation 3:

$\log _{10}\left(S_{\max }+1\right)=-\log _{10}\left(1-I_{\max }\right)$ 
Where $S_{\max }$ and $I_{\max }$ are the fold-increase and fractional-decrease in parameter value, respectively. Using this relationship, an example 9-fold stimulation of $\delta$ and c $\left(S_{\max }\right)$ would provide equivalent inhibition of $\beta$ and $\rho\left(I_{\max }=90 \%\right)$.

A total of eight intervention cases were simulated from model-derived parameters (Table 2 ). A base case no-intervention (referred to as "None") was included as reference. Four monotherapy interventions were simulated with equivalent effect size (93.7\% inhibition or 14.8 -fold stimulation). These response metrics were based on monotherapy effect sizes that would yield an $R_{0}$ approximating 1 , which is the threshold for an infection to be established. Thus, a $93.7 \%$ inhibition or 14.8-fold stimulation of a given parameter would correspond to a $6 / 5 \log _{10}$ change to result in a $\mathrm{R}_{0}<1$ (estimated in the target cell-limited model). Additionally, three combination interventions were simulated with equivalent effect size as that in the monotherapy setting, assuming additivity, divided equally across multiple viral life-cycle pathways. For example, a $6 / 5$ $\log _{10}$ change in one parameter were additively assumed to equate $2 / 5 \log _{10}$ changes each if three parameters were simultaneously targeted. These combinations represent modest effect $60.2 \%$ and $74.9 \%$ inhibition and 1.51-fold and 2.98-fold stimulation), and were intended to demonstrate the possible benefit of combinations each with moderate response.

For each dosing scenario, interventions on days $0,3,5$, and 10 after infection were simulated to study the effects of pre-exposure prophylaxis, post-exposure prophylaxis, symptom onset and post-symptom onset timing of interventions, respectively. A total of 1000 subjects were simulated at each of the eight interventions with BSV incorporated.

Simulated viral load and target epithelial cell pool data were summarised for each virtual subject. Four summary endpoints were considered including Detectable Viral Test $(>100$ copies $/ \mathrm{mL}$, which is a common lower-limit of detection for SARS-CoV-2 swabs), Modified $R_{0}$ (recalculated for each virtual subject, and is generally reduced after intervention),Duration of Viral Shedding, and Target Cell Pool Remaining . The detectable viral test and duration of viral shedding are a proxy for infection establishment, such that suppression of viral load produces subjects that may not be symptomatic or infectious. From VK modelling theory, reducing $R_{0}$ to a value below 1 is necessary to quench the exponential growth of viral load within a virtual subject. This metric provides a measure of the infection period, which would end in subjects with $R_{0}>1$ once the epithelial target pool is substantially exhausted. In contrast, $R_{0}<1$ suggests that the infection will end prior to that point. Lastly, the proportion of target epithelial cell pool remaining gives an indication of lung involvement, since disease outcome possibly correlates with the degree of airway lining infection.

\section{Results}

\section{Infection Severity in the Viral Load Data}

The pooled SARS-CoV-2 analysis dataset included subjects at varying degrees of infection severity (mild, mild-to-moderate, moderate, severe, and uncomplicated). In two studies ${ }^{28,33}$, infection severity was not reported for individual subjects, and were therefore categorized as unknown. Viral load exposures (AUC, peak, and time at maximum virus) were computed and summarized by degree of infection (Supplemental Table 1 ). To account for assay-specific differences, exposure metrics were additionally calculated after normalizing viral load observations to the defined LLOQ in each study. In the current analysis dataset, no apparent differences in LOQ-normalized viral load exposures were observed across the various degrees of infection severity (Supplemental Figure 1 ). Generally, the viral load profiles were comparable between studies and across patient populations.

\section{SARS-CoV-2 Kinetic Model}

The VK of SARS-CoV-2 in untreated subjects was described using a target cell-limited model (Equation 1). To reduce non-identifiability, three parameters $\left(R_{0}, \rho\right.$, and $\left.\delta\right)$ were estimated, with the remaining $\left(T_{0}, V_{0}\right.$ ,$k$ and $c$ ) fixed to physiologically plausible values.

The estimated basic reproductive number $\left(R_{0},\right)$, release rate of virus $(\rho)$ and infected cell mortality $(\delta)$ 
were 14.3, 49.9 copies $/ \mathrm{mL}^{-1} \mathrm{~d}^{-1}$ and $1.20 \mathrm{~d}^{-1}$, respectively (Table 3 ). Terms describing the BSV could only be estimated on $\delta$, possibly because of the lack of data to inform the model in the viral growth phase (from time of infection to symptom onset, assumed as 5 days in the model). No discernible differences in the BSV $\delta$ and degree of infection severity were identified (Supplemental Figure 2 ), and the influence of covariates were therefore not explored. Residual random error represents, in part, the considerable variability associated with nasopharyngeal sampling and potentially unavoidable inaccuracies arising from data digitization. The analysis utilizes pooled data across multiple studies, which measure viral load using different assays and detection limits. However, stratification of the residual error into studies with broadly comparable LLOQ did not improve standard model diagnostics or performance (data not shown). The simplest model (defined by the parameters reported in Table 3) was therefore selected as final. Reasonable predictive performance of this final model was shown by Visual Predictive Check (Figure 3 ).

\section{Simulated Intervention Outcomes}

A total of eight intervention scenarios were simulated $(\mathrm{N}=1000$ subjects per scenario) to demonstrate the effect of single dose and combination therapies that target each component of the viral life-cycle. These included a base case no-intervention reference ("(None)"), which simulated the SARS-CoV-2 time course using the parameter estimates from the developed target cell-limited model. Since the infectivity rate $\beta$ is a potential drug target, modulation of this parameter was incorporated, by re-arranging the model estimated $\mathrm{R}_{0}$ (Equation 2).

At base case where $R_{0}$ is 14.2 , the duration of viral shedding approximates 10 days (Figure 4 ), subjects were predicted to have detectable viral load (Figure 5 ), and no epithelial target pool remained (Figure 6 ). These data were compared to outcomes when interventions were administered at 0 days (pre-exposure prophylaxis), 3 days (post-exposure prophylaxes), 5 days (at symptom onset), and 10 days (post-symptom onset). Given $a n R_{0}$ of 14.2 , the effect sizes presented inTable 2 would result in modified reproductive number less than one $\left(R_{0}=14.2 \times(1-0.937)=0.895\right)$, which suggests that the infection can be halted with monotherapy, if applied at the time of infection. Descriptive summaries of projected endpoints for all interventions simulated are provided in Table $\mathbf{4}$, together with median viral load curves against base case (Figures 4-6).

Pre-exposure prophylaxis (day 0) targeting virion release $(\rho)$ and infected cell elimination $(\delta)$ yielded no subjects with a detectable viral test, zero days of viral shedding, and complete preservation of the target epithelial cell pool. By design, these interventions modify $R_{0}$ to $<1$. Interventions focusing on target cell infection $(\beta)$ and virion elimination ( $c$ ) yield modified $R_{0}$ that were slightly above 1 , as $c$ and $\beta$ appear as a sum in the denominator of $R_{0}$ (Equation 2). As such, these forms of interventions are predicted to produce a slowly-progressing, limited infection.

Post-exposure prophylaxes (day 3 ) and interventions at symptom onset (day 5) have similar trends, with interventions on target cell infectivity $(\beta)$ yielding the longest duration of viral shedding. In contrast, interventions that stimulate infected cell elimination $(\delta)$ were predicted to halve the duration of viral shedding. Other interventions provided intermediate results. Interestingly, combinations featuring virion release $(\rho)$ and infected cell elimination $(\delta)$ offered similar benefit to monotherapy, but required a more modest effect size. Treatment at Day 10 after symptom onset provided very little therapeutic benefit, and had VK profiles that were similar to no intervention.

\section{Discussion}

The current analysis utilized published viral load data in symptomatic patients confirmed with SARS-CoV-2 infection. Data were digitized and pooled from 13 publications containing a total of 105 subjects, with a mixture of disease severity including mild, moderate, and severe infection. To our knowledge, this is the largest available SARS-CoV-2 viral load dataset which provides a robust estimation of VK parameters and patient heterogeneity. Previous analyses have utilized much smaller datasets to provide an initial quantification of SARS-CoV-2 in patients. ${ }^{1,2,21,40}$. The model estimated basic reproductive number $\left(\mathrm{R}_{0}\right.$ $=14.2$, which is similar to somewhat less than estimates for influenza ${ }^{16}$. This value was reasonably well 
estimated and provides key information to suggest that relatively strong drug potencies are required to quench SARS-CoV-2 infection. Furthermore, this analysis provides an improved understanding of the population variability in peak viral load and duration of shedding, both of which inform the optimal times for treatment initiation.

Overall, the viral load profiles for SARS-CoV-2 demonstrated some differences from other respiratory viruses. For influenza and RSV, the time between infection and clinical symptom onset is short ( 1 and 3 days, respectively), with peak viral load occurring at 2 and 6 days, respectively ${ }^{16-18}$. Symptom appearance and corresponding diagnosis is considerably longer (range 5-24 days) ${ }^{14}$ for SARS-CoV-2, and may occur close to the time of maximal virus. This is a troublesome finding, as it practically suggests that diagnosis of COVID-19 based on symptomatology occurs late in the viral life cycle, reducing the opportunity for early intervention with antiviral agents. Simulations from our model suggest that peak viral titre results at 3 to 5 days post-infection. Furthermore, while the simulated median duration of viral shedding (10 days) is slightly longer than influenza or RSV ( 8 days), this endpoint is $2-3$-fold longer in some subjects with SARSCov-2 infection ${ }^{41}$. As additional viral load data emerge across larger and more diverse patient populations, investigators should continue to identify differences in VK profiles, which may potentially predict disease course or severity.

Analysis of the VK profiles using an established target cell-limited model provided estimates that may provide insights into the pathophysiology of SARS-CoV-2 infection. The basic reproductive number $\left(R_{0}\right)$ and virion release rates $(\rho)$ were relatively high, with estimates approximating 14 and 50 copies $/ \mathrm{mL} . \mathrm{d}^{-1}$, respectively. For other coronaviruses, the burst size $(\rho)$ range has been shown to range from 10 to 700 virions that can produce secondary infections ${ }^{42,43}$. While the data indicate substantial variability in the SARS-CoV-2 profiles, BSV could only be estimated on the infected cell mortality rate $(\delta)$. This challenge potentially occurred due to the lack of data to inform estimation from the time of infection to symptom onset (assumed as 5 days). Despite this limitation, reasonable estimates and predictive performance were obtained. Further improvements may occur as subsequent data describing the SARS-CoV-2 incubation period become available.

One key result of the simulations is that earlier intervention is critical for effective treatment of SARS-CoV-2. This is not a surprise, and consistent with both VK models and clinical trials for other respiratory viruses, including influenza ${ }^{16,44,45}$. As time to therapy initiation increases, the ability for an antiviral to produce a clinically relevant impact on viral load, and presumably, disease course, decreases. Pre-exposure prophylaxis (day 0) may be utilized in a high risk population, or in a contact tracing scenario. Post-exposure prophylaxis (day 3 after infection, prior to symptom onset) is possible in the setting of a known infection, or in cases where widespread rapid testing is available, or as part of a contact tracing process. These two intervention modes appear to provide better success with drugs of marginal potency, which are likely when repurposing existing drugs and/or with non-optimized new and emerging treatments. Some interventions on or after symptom onset appear to reduce the duration of viral shedding (perhaps reducing forward transmission), but have minimal effect on the target cell pool population.

The impact of time to initiate treatment is dependent on the viral load profile of individual patients. Due to the underlying heterogeneity in VK, a portion of patients may still benefit from treatment initiated later in the disease course. Reduced therapeutic efficacy may occur in other subjects, even if treatment occurs relatively early. Another key finding is that combination therapies with drugs that have moderate antiviral activity may offer the potential to match the efficacy of more potent monotherapies. In the context of repurposing, where the antiviral activity of a candidate drug may be underwhelming, two or three combinations may offer a path forward. That said, simulations from the current model suggest a rank-ordering of ideal interventions: $\delta>\rho, c>\beta$.

The model provides some insights into potential mechanisms of action of antiviral drugs, and how the various mechanisms might influence viral load. Inhibition of infectivity $(\beta)$, such as a cell entry inhibitor, is predicted to have modest impact on viral load once infection is established $\left(\mathrm{R}_{0}>1\right)$. If beta is inhibited by $93.7 \%$ at 3 days post infection, the modified mean $R_{0}$ is reduced, but is still above the threshold to establish a new 
infection. Comparatively, the infection is quenched $\left(\mathrm{R}_{0}<1\right)$ if the same degree of enhancement of effect on clearance of infected cells $(\delta)$ at 3 days post-infection.

There are several key limitations to this current analysis. The data were digitized from multiple studies, for which viral load measurement was performed in different labs, with varying LLOQ and sensitivity or specificity. Therefore, differences in sample collection, processing, and assay may have contributed additional variability and uncertainty to the analysis dataset. However, inter-study comparison of viral load profiles were generally comparable, suggesting that pooling of the data was not unreasonable. Most of the VK data were measured after clinical symptom onset, with negligible data available to inform estimation of the period between infection and this occurrence. Simulations from the model, however, provide the advantage of visualizing this aspect of the VK curve, thereby providing an understanding on the kinetics of viral replication. Additional sources of viral load data, particularly from well-controlled clinical trials, are expected in the future, and similar analyses using such datasets is encouraged.

\section{Conclusions}

In the current manuscript, we use a modelling and simulation approach to characterize the time course of SARS-CoV-2, with applications including guiding effective prophylactic and treatment interventions. Similar in silico frameworks can be used prospectively, to better handle current and future pandemics. Based on model simulation, we propose the following generalized guidelines for respiratory infection:

1. A robust estimate of the basic reproductive number may provide useful insights around the drug potency required for effectiveness;

2. If the time between infection and symptom onset is short $(<3-5$ days, such as for influenza), there is a greater opportunity to intervene early in the course of the viral life-cycle. Delayed clinical symptom onset post-infection, as appears to be with coronavirus, reduces the likelihood of early intervention, and hence requires more potent therapies to provide a clinically meaningful impact.

3. Interventions which enhance the immune response, or increase clearance of infected cells, if available, appear to be the more attractive drug targets. Drugs such as entry inhibitors are less likely to have a role in managing an established infection.

\section{Acknowledgements}

We thank Dr Jeremie Guedj for suggestions on development of the target cell-limited model. We thank Dr Nancy Zhang and Carolyn Winskill for viral load data digitization.

\section{References}

1. Gonçalves A, Bertrand J, Ke R, et al. Timing of antiviral treatment initiation is critical to reduce SARS-Cov-2 viral load. medRxiv.2020:2020.2004.2004.20047886.

2. Goyal A, Cardozo-Ojeda EF, Schiffer JT. Potency and timing of antiviral therapy as determinants of duration of SARS CoV-2 shedding and intensity of inflammatory response. medRxiv.2020:2020.2004.2010.20061325.

3. Rayner CR, Dron L, Park JJH, et al. Accelerating Clinical Evaluation of Repurposed Combination Therapies for COVID-19. Am J Trop Med Hyg. 2020.

4. Rayner CR, Smith PF, Hershberger K, Wesche D. Optimizing COVID-19 Candidate Therapeutics: Thinking Without Borders. Clin Transl Sci. 2020.

5. Smith PF, Dodds M, Bentley D, Yeo K, Rayner C. Dosing will be a key success factor in repurposing antivirals for COVID-19. Br J Clin Pharmacol. 2020.

6. Allerheiligen SR. Impact of modeling and simulation: myth or fact? Clin Pharmacol Ther. 2014;96(4):413415.

7. Milligan PA, Brown MJ, Marchant B, et al. Model-based drug development: a rational approach to efficiently accelerate drug development. Clin Pharmacol Ther. 2013;93(6):502-514. 
8. Stone JA, Banfield C, Pfister M, et al. Model-based drug development survey finds pharmacometrics impacting decision making in the pharmaceutical industry. J Clin Pharmacol. 2010;50(9 Suppl):20S-30S.

9. Kamal MA, Smith PF, Chaiyakunapruk N, et al. Interdisciplinary pharmacometrics linking oseltamivir pharmacology, influenza epidemiology and health economics to inform antiviral use in pandemics. Br J Clin Pharmacol. 2017;83(7):1580-1594.

10. Xu X, Chen P, Wang J, et al. Evolution of the novel coronavirus from the ongoing Wuhan outbreak and modeling of its spike protein for risk of human transmission. Sci China Life Sci. 2020;63(3):457-460.

11. Backer JA, Klinkenberg D, Wallinga J. Incubation period of 2019 novel coronavirus (2019-nCoV) infections among travellers from Wuhan, China, 20-28 January 2020. Euro Surveill. 2020;25(5).

12. Li Q, Guan X, Wu P, et al. Early Transmission Dynamics in Wuhan, China, of Novel Coronavirus-Infected Pneumonia. N Engl J Med.2020;382(13):1199-1207.

13. Influenza. Principles and Practice of Clinical Virology :271-297.

14. Zhou F, Yu T, Du R, et al. Clinical course and risk factors for mortality of adult inpatients with COVID-19 in Wuhan, China: a retrospective cohort study. Lancet. 2020;395(10229):1054-1062.

15. He X, Lau EHY, Wu P, et al. Temporal dynamics in viral shedding and transmissibility of COVID-19. Nat Med. 2020;26(5):672-675.

16. Baccam P, Beauchemin C, Macken CA, Hayden FG, Perelson AS. Kinetics of influenza A virus infection in humans. J Virol.2006;80(15):7590-7599.

17. Canini L, Carrat F. Population modeling of influenza A/H1N1 virus kinetics and symptom dynamics. $J$ Virol. 2011;85(6):2764-2770.

18. DeVincenzo JP, Wilkinson T, Vaishnaw A, et al. Viral load drives disease in humans experimentally infected with respiratory syncytial virus. Am J Respir Crit Care Med. 2010;182(10):1305-1314.

19. Korell J, Green B, DeVincenzo J, Huntjens D. A human challenge model for respiratory syncytial virus kinetics, the pharmacological effect of a novel fusion inhibitor, and the modelling of symptoms scores.Eur $J$ Pharm Sci. 2017;109s:S154-s160.

20. Patel K, Kirkpatrick CM, Nieforth KA, et al. Respiratory syncytial virus-A dynamics and the effects of lumicitabine, a nucleoside viral replication inhibitor, in experimentally infected humans. J Antimicrob Chemother. 2019;74(2):442-452.

21. Kim KS, Ejima K, Ito Y, et al. Modelling SARS-CoV-2 Dynamics: Implications for Therapy. medRxiv. 2020:2020.2003.2023.20040493.

22. Cheng CY, Lee YL, Chen CP, et al. Lopinavir/ritonavir did not shorten the duration of SARS CoV-2 shedding in patients with mild pneumonia in Taiwan. J Microbiol Immunol Infect.2020;53(3):488-492.

23. Han MS, Seong MW, Kim N, et al. Viral RNA Load in Mildly Symptomatic and Asymptomatic Children with COVID-19, Seoul. Emerg Infect Dis.2020;26(10).

24. Kim ES, Chin BS, Kang CK, et al. Clinical Course and Outcomes of Patients with Severe Acute Respiratory Syndrome Coronavirus 2 Infection: a Preliminary Report of the First 28 Patients from the Korean Cohort Study on COVID-19. J Korean Med Sci. 2020;35(13):e142.

25. Kim JY, Ko JH, Kim Y, et al. Viral Load Kinetics of SARS-CoV-2 Infection in First Two Patients in Korea. J Korean Med Sci.2020;35(7):e86.

26. Kim SE, Jeong HS, Yu Y, et al. Viral kinetics of SARS-CoV-2 in asymptomatic carriers and presymptomatic patients. Int J Infect Dis. 2020;95:441-443. 
27. Lescure FX, Bouadma L, Nguyen D, et al. Clinical and virological data of the first cases of COVID-19 in Europe: a case series.Lancet Infect Dis. 2020;20(6):697-706.

28. Lui G, Ling L, Lai CK, et al. Viral dynamics of SARS-CoV-2 across a spectrum of disease severity in COVID-19. The Journal of infection. 2020:S0163-4453(0120)30225-30225.

29. Thevarajan I, Nguyen THO, Koutsakos M, et al. Breadth of concomitant immune responses prior to patient recovery: a case report of non-severe COVID-19. Nature medicine. 2020;26(4):453-455.

30. Wölfel R, Corman VM, Guggemos W, et al. Virological assessment of hospitalized patients with COVID2019. Nature.2020;581(7809):465-469.

31. Young BE, Ong SWX, Kalimuddin S, et al. Epidemiologic Features and Clinical Course of Patients Infected With SARS-CoV-2 in Singapore.Jama. 2020;323(15):1488-1494.

32. Zou L, Ruan F, Huang M, et al. SARS-CoV-2 Viral Load in Upper Respiratory Specimens of Infected Patients. N Engl J Med.2020;382(12):1177-1179.

33. Kawasuji H, Takegoshi Y, Kaneda M, et al. Viral load dynamics in transmissible symptomatic patients with COVID-19. medRxiv.2020:2020.2006.2002.20120014.

34. Yoon JG, Yoon J, Song JY, et al. Clinical Significance of a High SARS-CoV-2 Viral Load in the Saliva. J Korean Med Sci.2020;35(20):e195.

35. Muus C, Luecken MD, Eraslan G, et al. Integrated analyses of single-cell atlases reveal age, gender, and smoking status associations with cell type-specific expression of mediators of SARS-CoV-2 viral entry and highlights inflammatory programs in putative target cells.bioRxiv. 2020:2020.2004.2019.049254.

36. Best K, Guedj J, Madelain V, et al. Zika plasma viral dynamics in nonhuman primates provides insights into early infection and antiviral strategies. Proc Natl Acad Sci U S A. 2017;114(33):8847-8852.

37. Agostini ML, Andres EL, Sims AC, et al. Coronavirus Susceptibility to the Antiviral Remdesivir (GS5734) Is Mediated by the Viral Polymerase and the Proofreading Exoribonuclease. mBio. 2018;9(2).

38. Lauer SA, Grantz KH, Bi Q, et al. The Incubation Period of Coronavirus Disease 2019 (COVID-19) From Publicly Reported Confirmed Cases: Estimation and Application. Ann Intern Med.2020;172(9):577-582.

39. Bergstrand M, Karlsson MO. Handling data below the limit of quantification in mixed effect models. Aaps j.2009;11(2):371-380.

40. Dodds MG, Krishna R, Goncalves A, Rayner CR. Model-Informed Drug Repurposing: Viral Kinetic Modeling to Prioritize Rational Drug Combinations for COVID-19. Br J Clin Pharmacol. 2020.

41. Qian GQ, Chen XQ, Lv DF, et al. Duration of SARS-CoV-2 viral shedding during COVID-19 infection. Infect Dis (Lond).2020;52(7):511-512.

42. Bar-On YM, Flamholz A, Phillips R, Milo R. SARS-CoV-2 (COVID-19) by the numbers. Elife. 2020;9.

43. Robb JA, Bond CW. Coronaviridae. In: Fraenkel-Conrat H, Wagner RR, eds. Comprehensive Virology: Newly Characterized Vertebrate Viruses . Boston, MA: Springer US; 1979:193-247.

44. Kamal MA, Gieschke R, Lemenuel-Diot A, Beauchemin CA, Smith PF, Rayner CR. A drug-disease model describing the effect of oseltamivir neuraminidase inhibition on influenza virus progression. Antimicrob Agents Chemother. 2015;59(9):5388-5395.

45. Aoki FY, Macleod MD, Paggiaro P, et al. Early administration of oral oseltamivir increases the benefits of influenza treatment. J Antimicrob Chemother. 2003;51(1):123-129.

Tables

Table 1 Summary of viral load studies used to estimate SARS-CoV-2 viral kinetics 


\begin{tabular}{|c|c|c|c|c|c|c|c|}
\hline Study & $\mathrm{N}$ subjects & $\mathrm{N}$ subjects & $\mathrm{N}$ subjects & Observations & LOQ & BLQ (\%) & $\mathrm{P}$-value ${ }^{\mathrm{g}}$ \\
\hline & Total & Untreated & Treated (drugs) & & & & \\
\hline Cheng et al. ${ }^{22}$ & 5 & 3 & $2(\mathrm{LPV} / \mathrm{r})$ & $42^{\mathrm{a}}$ & $\mathrm{Ct}=40$ & 0.00 & 0.584 \\
\hline Han et al. ${ }^{23}$ & 9 & 9 & 0 & $49^{\mathrm{b}, \mathrm{e}}$ & $\log _{10}=4.10$ & 18.4 & - \\
\hline Kawasuji et al. 33 & 18 & 0 & $18^{\mathrm{f}}$ & $56^{\mathrm{c}}$ & $\log =-0.4$ & 42.9 & - \\
\hline Kim et al. ${ }^{24}$ & 9 & 2 & $7(\mathrm{LPV} / \mathrm{r})$ & $70^{\mathrm{a}}$ & $\mathrm{Ct}=38$ & 22.9 & 0.207 \\
\hline Kim et al. ${ }^{26}$ & 3 & 2 & $1(\mathrm{LPV} / \mathrm{r})$ & $20^{\mathrm{a}}$ & $\mathrm{Ct}=35$ & 40.0 & - \\
\hline Kim et al. ${ }^{25}$ & 1 & 1 & 0 & $14^{\mathrm{b}}$ & $\log _{10}=3.43$ & 21.4 & - \\
\hline Lescure et al. ${ }^{27}$ & 4 & 2 & $2(\mathrm{RDV})$ & $38^{\mathrm{b}}$ & $\log _{10}=2.00$ & 31.6 & 0.236 \\
\hline Lui et al. ${ }^{28}$ & 11 & 11 & 0 & $40^{\mathrm{d}}$ & $\log _{10}=2.84$ & 0.00 & - \\
\hline Thevarajan et al. ${ }^{29}$ & 1 & 1 & 0 & $6^{\mathrm{a}}$ & $\mathrm{Ct}=45$ & 66.7 & - \\
\hline Wolfel et al. ${ }^{30}$ & 9 & 9 & 0 & $153^{\mathrm{b}}$ & $\log _{10}=2.00$ & 63.4 & - \\
\hline Yoon et al. ${ }^{34}$ & 1 & 0 & $1(\mathrm{LPV} / \mathrm{r})$ & $5^{\mathrm{b}}$ & $\log _{10}=3.00$ & 0.00 & - \\
\hline Young et al. ${ }^{31}$ & 18 & 13 & $5(\mathrm{LPV} / \mathrm{r})$ & $230^{\mathrm{a}}$ & $\mathrm{Ct}=38$ & 20.4 & 0.455 \\
\hline Zou et al. ${ }^{32}$ & 16 & 16 & 0 & $65^{\mathrm{a}}$ & $\mathrm{Ct}=40$ & 24.6 & - \\
\hline All studies & 105 & 69 & 36 & 788 & - & 29.9 & 0.211 \\
\hline
\end{tabular}

a, b, c, d Cycle threshold (Ct), $\log _{10}$ copies/mL, log copies/ $\mu \mathrm{L}$, and copies/mL units, respectively.

e Only paediatric study in analysis population.

${ }^{\mathrm{f}}$ Authors report a combination of antivirals and antibiotics.

g Non-significance in observed viral load area under the curve between untreated and treatment subjects.

Abbreviations: BLQ, below the limit of quantitation; Ct, cycle threshold; LPV/r, lopinavir/ritonavir; RDV, remdesevir.

Table 2 Simulated study designs used to stimulate or inhibit target sites in the SARS-CoV-2 life-cycle

\begin{tabular}{lllll}
\hline Intervention & $\beta$ (Target Cell Infection) & $\rho$ (Virion Release) & $\delta$ (Infected Cell Elimination) & $\mathrm{c}$ (Virion Elimin \\
\hline (None) & $0[0 \%$ Inhibition] & $0[0 \%$ Inhibition] & 0 [0-fold Stimulation] & 0 [0-fold Stimul \\
$\beta=6 / 5$ & $6 / 5[93.7 \%$ Inhibition] & $0[0 \%$ Inhibition] & 0 [0-fold Stimulation] & 0 [0-fold Stimul \\
$\rho=6 / 5$ & $0[0 \%$ Inhibition] & $6 / 5[93.7 \%$ Inhibition] & 0 [0-fold Stimulation] & 0 [0-fold Stimul \\
$\delta=6 / 5$ & $0[0 \%$ Inhibition] & $0[0 \%$ Inhibition] & $6 / 5$ [14.8-fold Stimulation] & $0[0$-fold Stimul \\
$c=6 / 5$ & $0[0 \%$ Inhibition] & $0[0 \%$ Inhibition] & $0[0$-fold Stimulation] & $6 / 5[14.8$-fold S \\
$\rho=2 / 5 \delta=2 / 5 \mathrm{c}=2 / 5^{\mathrm{b}}$ & $0[0 \%$ Inhibition] & $2 / 5[60.2 \%$ Inhibition] & $2 / 5[1.51$-fold Stimulation] & $2 / 5[1.51$-fold S \\
$\beta=2 / 5 \rho=2 / 5 \delta=2 / 5$ & $2 / 5[60.2 \%$ Inhibition] & $2 / 5[60.2 \%$ Inhibition] & $2 / 5[1.51$-fold Stimulation] & $0[0$-fold Stimul \\
$\rho=3 / 5 \delta=3 / 5$ & $0[0 \%$ Inhibition] & $3 / 5[74.9 \%$ Inhibition] & $3 / 5[2.98$-fold Stimulation] & 0 [0-fold Stimul \\
\hline
\end{tabular}

a A $6 / 5 \log _{10}$ change corresponds to a $93.7 \%$ inhibition or 14.8 -fold stimulation of that parameter, obtained using the estimated $\mathrm{R}_{0}$ from the model.

b Additivity is applied to combination therapies providing the same effect size to monotherapy if treatment was to occur at the time of infection.

Table 3 Parameter estimates from the target cell-limited model

\begin{tabular}{llll}
\hline Parameter (unit) & Description & Population Mean (\%RSE) & $\eta$ shrinkage \\
\hline$R_{0}(-)$ & Basic reproduction number & $14.2(1.90)$ & -
\end{tabular}




\begin{tabular}{llll}
\hline Parameter $($ unit $)$ & Description & Population Mean $(\% \mathrm{RSE})$ & $\eta$ shrinkage \\
\hline$p\left(\right.$ copies $\left./ \mathrm{mL} \cdot \mathrm{d}^{-1}\right)$ & Viral production/release rate & $49.9(2.30)$ & - \\
$\delta\left(\mathrm{d}^{-1}\right)$ & Infected cell mortality rate & $1.20(7.90)$ & - \\
$T_{0}($ cells $/ \mathrm{mL})$ & Initial target epithelial cells & $1.33 \times 10^{5} \mathrm{FIX}$ & - \\
$V_{0}($ copies $/ \mathrm{mL})$ & Initial viral load & $10.0 \mathrm{FIX}$ & - \\
$k\left(\mathrm{~d}^{-1}\right)$ & Eclipse (transition) rate & $3.0 \mathrm{FIX}$ & - \\
$c\left(\mathrm{~d}^{-1}\right)$ & Free virus elimination rate & $10.0 \mathrm{FIX}$ & - \\
$B \Sigma^{\circ} \delta(\% \mathrm{CV})$ & Inter-individual variability on $\delta$ & $54.2(18.1)$ & 29.6 \\
Log-additive error $($ cells $/ \mathrm{mL})$ & Residual error & $2.90(5.76)$ & 7.32 \\
\hline
\end{tabular}

Abbreviations: BSV, between subject variability represented as a coefficient of variation (CV); RSE, Relative Standard Error.

Table 4 Simulated viral kinetic outcomes following intervention at various times after infection

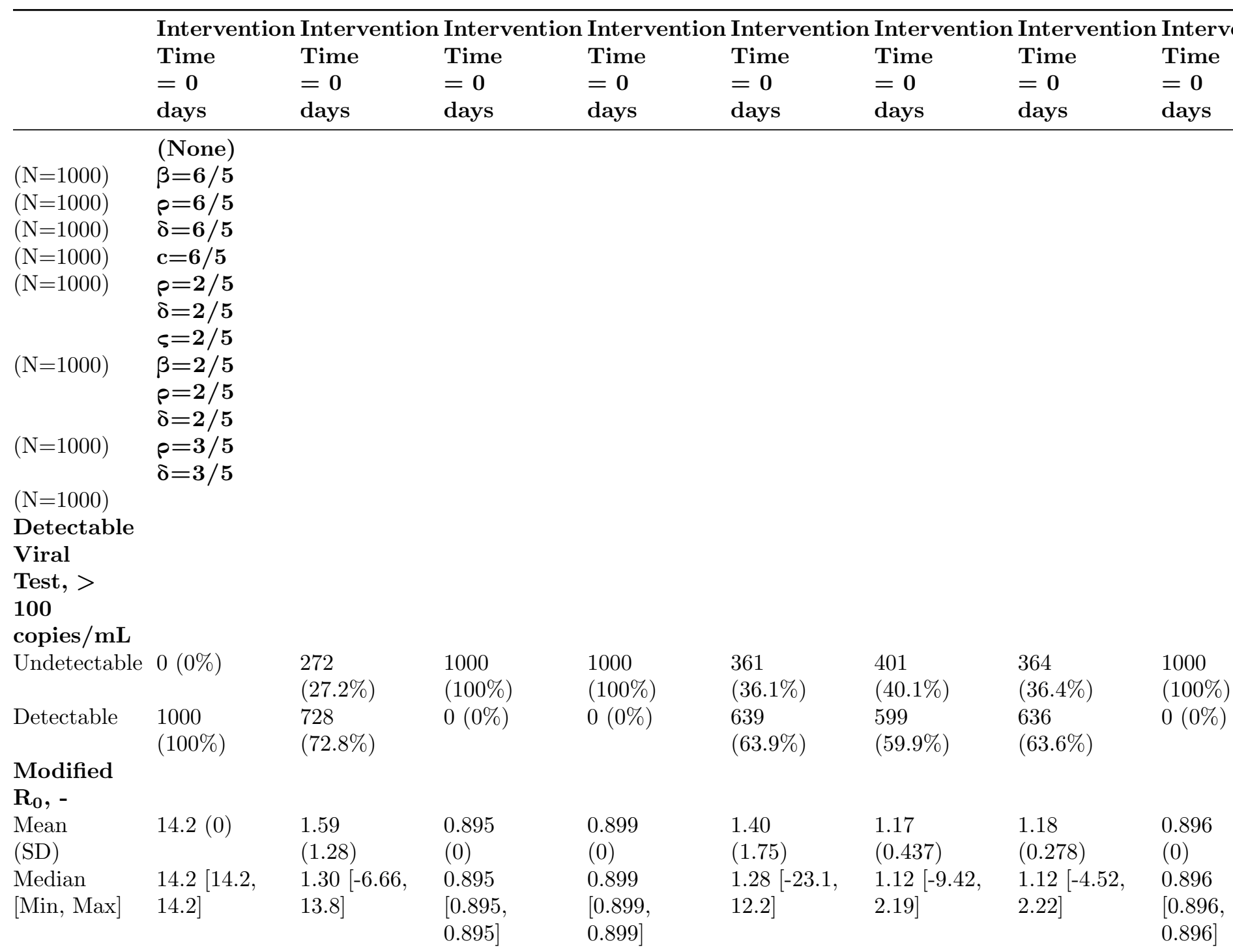




\begin{tabular}{|c|c|c|c|c|c|c|c|c|}
\hline & $\begin{array}{l}\text { Interventi } \\
\text { Time } \\
=0 \\
\text { days }\end{array}$ & $\begin{array}{l}\text { Interve } \\
\text { Time } \\
=0 \\
\text { days }\end{array}$ & $\begin{array}{l}\text { Intervent } \\
\text { Time } \\
=0 \\
\text { days }\end{array}$ & $\begin{array}{l}\text { Intervent } \\
\text { Time } \\
=0 \\
\text { days }\end{array}$ & $\begin{array}{l}\text { Interve } \\
\text { Time } \\
=0 \\
\text { days }\end{array}$ & $\begin{array}{l}\text { Interve } \\
\text { Time } \\
=0 \\
\text { days }\end{array}$ & $\begin{array}{l}\text { Interve } \\
\text { Time } \\
=0 \\
\text { days }\end{array}$ & $\begin{array}{l}\text { Interv } \\
\text { Time } \\
=0 \\
\text { days }\end{array}$ \\
\hline \multicolumn{9}{|l|}{$\begin{array}{l}\text { Duration } \\
\text { of } \\
\text { Shed- } \\
\text { ding, } \\
\text { days }\end{array}$} \\
\hline $\begin{array}{l}\text { Mean } \\
\text { (SD) }\end{array}$ & $\begin{array}{l}10.7 \\
(5.76)\end{array}$ & $\begin{array}{l}17.7 \\
(14.3)\end{array}$ & $0(0)$ & $0(0)$ & $\begin{array}{l}9.62 \\
(9.14)\end{array}$ & $\begin{array}{l}9.40 \\
(9.21)\end{array}$ & $\begin{array}{l}12.9 \\
(12.0)\end{array}$ & $0(0)$ \\
\hline $\begin{array}{l}\text { Median } \\
\text { [Min, Max] } \\
\text { Target } \\
\text { Pool } \\
\text { Re- } \\
\text { main- } \\
\text { ing, } \\
\text { \% }\end{array}$ & $\begin{array}{l}9.00[3.46, \\
47.8]\end{array}$ & $\begin{array}{l}17.7[0 \\
41.4]\end{array}$ & $0[0,0]$ & $0[0,0]$ & $\begin{array}{l}8.63[0, \\
28.0]\end{array}$ & $\begin{array}{l}8.62[0 \\
26.4]\end{array}$ & $\begin{array}{l}12.0[0 \\
34.5]\end{array}$ & $0[0,0]$ \\
\hline $\begin{array}{l}\text { Mean } \\
(\mathrm{SD})\end{array}$ & $0(0)$ & $\begin{array}{l}62.8 \\
(35.5)\end{array}$ & $\begin{array}{l}100 \\
(0.0267)\end{array}$ & $\begin{array}{l}100 \\
(0.0238)\end{array}$ & $\begin{array}{l}65.2 \\
(34.1)\end{array}$ & $\begin{array}{l}73.1 \\
(29.5)\end{array}$ & $\begin{array}{l}73.0 \\
(29.6)\end{array}$ & $\begin{array}{l}100 \\
(0.0250\end{array}$ \\
\hline $\begin{array}{l}\text { Median } \\
\text { [Min, Max] }\end{array}$ & $0[0,0]$ & $\begin{array}{l}63.4[0 \\
100]\end{array}$ & $\begin{array}{l}100[99.9 \\
100]\end{array}$ & $\begin{array}{l}100[99.9 \\
100]\end{array}$ & $\begin{array}{l}69.0[0, \\
100]\end{array}$ & $\begin{array}{l}82.4[0 \\
100]\end{array}$ & $\begin{array}{l}83.2[0 \\
100]\end{array}$ & $\begin{array}{l}100[99 \\
100]\end{array}$ \\
\hline
\end{tabular}

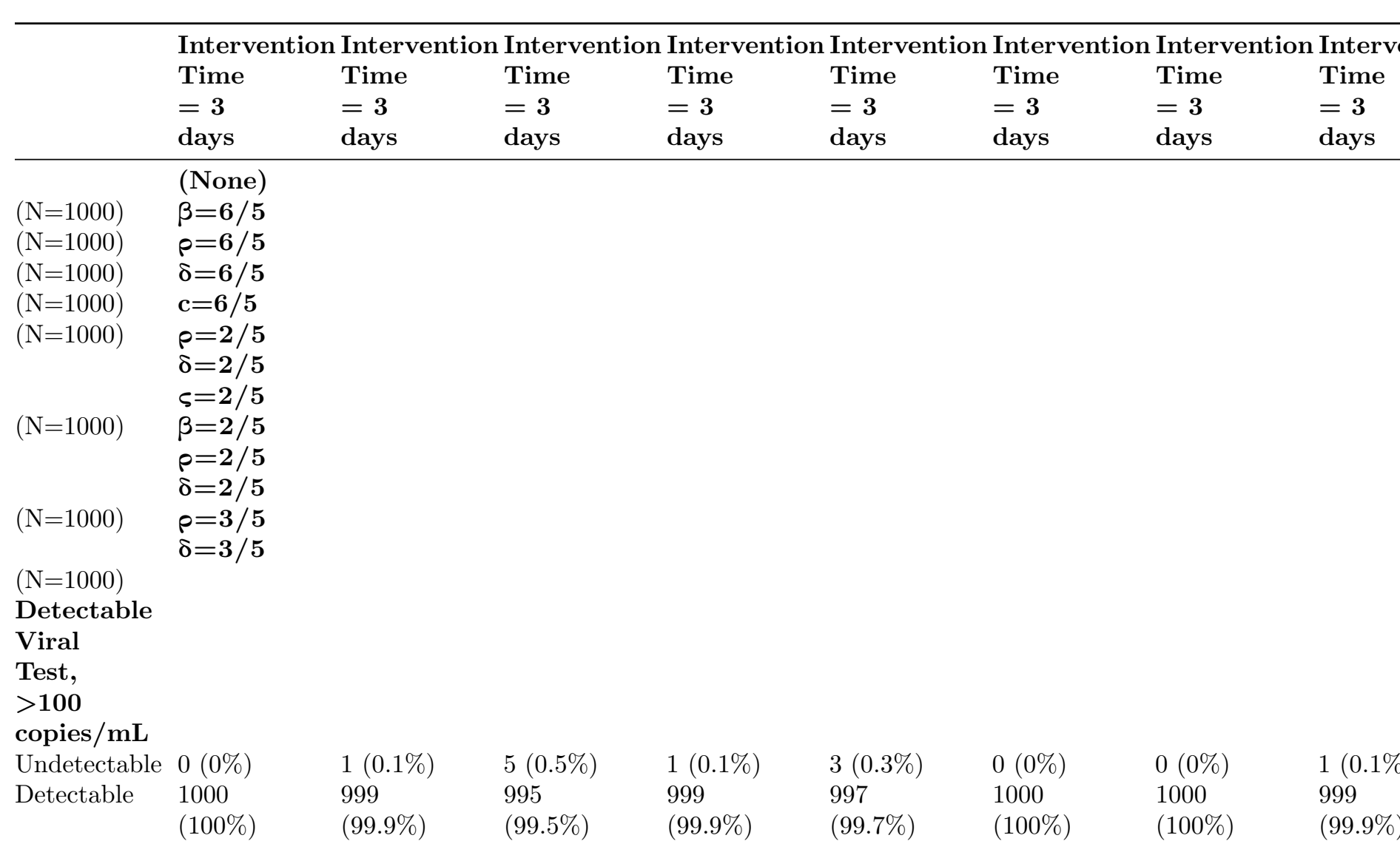




\begin{tabular}{|c|c|c|c|c|c|c|c|c|}
\hline & $\begin{array}{l}\text { Interventi } \\
\text { Time } \\
=3 \\
\text { days }\end{array}$ & $\begin{array}{l}\text { Interventic } \\
\text { Time } \\
=3 \\
\text { days }\end{array}$ & $\begin{array}{l}\text { Interven } \\
\text { Time } \\
=3 \\
\text { days }\end{array}$ & $\begin{array}{l}\text { Interve } \\
\text { Time } \\
=3 \\
\text { days }\end{array}$ & $\begin{array}{l}\text { Interventic } \\
\text { Time } \\
=3 \\
\text { days }\end{array}$ & $\begin{array}{l}\text { Interventic } \\
\text { Time } \\
=3 \\
\text { days }\end{array}$ & $\begin{array}{l}\text { Interventio } \\
\text { Time } \\
=3 \\
\text { days }\end{array}$ & $\begin{array}{l}\text { Inter } \\
\text { Time } \\
=3 \\
\text { days }\end{array}$ \\
\hline \multicolumn{9}{|l|}{ Modified } \\
\hline \multicolumn{9}{|l|}{$\mathbf{R}_{0}$} \\
\hline $\begin{array}{l}\text { Mean } \\
(\mathrm{SD})\end{array}$ & $14.2(0)$ & $\begin{array}{l}1.54 \\
(0.833)\end{array}$ & $\begin{array}{l}0.895 \\
(0)\end{array}$ & $\begin{array}{l}0.899 \\
(0)\end{array}$ & $\begin{array}{l}1.67 \\
(1.16)\end{array}$ & $\begin{array}{l}1.19 \\
(0.207)\end{array}$ & $\begin{array}{l}1.19 \\
(0.221)\end{array}$ & $\begin{array}{l}0.896 \\
(0)\end{array}$ \\
\hline $\begin{array}{l}\text { Median } \\
\text { [Min, Max] }\end{array}$ & $\begin{array}{l}14.2[14.2, \\
14.2]\end{array}$ & $\begin{array}{l}1.30[0.929, \\
13.4]\end{array}$ & $\begin{array}{l}0.895 \\
{[0.895} \\
0.895]\end{array}$ & $\begin{array}{l}0.899 \\
{[0.899,} \\
0.899]\end{array}$ & $\begin{array}{l}1.33[0.947, \\
13.6]\end{array}$ & $\begin{array}{l}1.13[0.936, \\
2.19]\end{array}$ & $\begin{array}{l}1.12[0.937, \\
2.24]\end{array}$ & $\begin{array}{l}0.896 \\
{[0.896,} \\
0.896]\end{array}$ \\
\hline \multicolumn{9}{|l|}{$\begin{array}{l}\text { Shed- } \\
\text { ding, } \\
\text { days }\end{array}$} \\
\hline $\begin{array}{l}\text { Mean } \\
\text { (SD) }\end{array}$ & $\begin{array}{l}10.3 \\
(4.79)\end{array}$ & $\begin{array}{l}18.5 \\
(16.8)\end{array}$ & $\begin{array}{l}9.66 \\
(6.57)\end{array}$ & $\begin{array}{l}4.93 \\
(2.21)\end{array}$ & $\begin{array}{l}11.3 \\
(10.9)\end{array}$ & $\begin{array}{l}7.50 \\
(6.10)\end{array}$ & $\begin{array}{l}9.70 \\
(9.13)\end{array}$ & $\begin{array}{l}6.15 \\
(3.53)\end{array}$ \\
\hline $\begin{array}{l}\text { Median } \\
\text { [Min, Max] }\end{array}$ & $\begin{array}{l}9.00[3.40, \\
41.2]\end{array}$ & $\begin{array}{l}9.94[0 \\
54.4]\end{array}$ & $\begin{array}{l}6.72[0 \\
25.4]\end{array}$ & $\begin{array}{l}4.00[0 \\
11.2]\end{array}$ & $\begin{array}{l}6.72[0, \\
51.1]\end{array}$ & $\begin{array}{l}4.61[0.180, \\
26.2]\end{array}$ & $\begin{array}{l}5.31[2.65 \\
39.1]\end{array}$ & $\begin{array}{l}4.55[0 \\
15.2]\end{array}$ \\
\hline $\begin{array}{l}\text { Target } \\
\text { Pool } \\
\text { Re- } \\
\text { main- } \\
\text { ing, } \\
\%\end{array}$ & & & & & & & & \\
\hline $\begin{array}{l}\text { Mean } \\
(\mathrm{SD})\end{array}$ & $0(0)$ & $\begin{array}{l}22.4 \\
(30.1)\end{array}$ & $\begin{array}{l}22.1 \\
(32.0)\end{array}$ & $\begin{array}{l}20.6 \\
(30.7)\end{array}$ & $\begin{array}{l}19.7 \\
(28.5)\end{array}$ & $\begin{array}{l}20.8 \\
(29.8)\end{array}$ & $\begin{array}{l}22.7 \\
(31.6)\end{array}$ & $\begin{array}{l}23.8 \\
(32.6)\end{array}$ \\
\hline \multirow[t]{5}{*}{$\begin{array}{l}\text { Median } \\
\text { [Min, Max] }\end{array}$} & $0[0,0]$ & $\begin{array}{l}2.85[0, \\
100]\end{array}$ & $\begin{array}{l}0.550[0, \\
100]\end{array}$ & $\begin{array}{l}1.00[0, \\
99.7]\end{array}$ & $\begin{array}{l}1.10[0, \\
99.9]\end{array}$ & $\begin{array}{l}1.30[0, \\
99.4]\end{array}$ & $\begin{array}{l}2.10[0, \\
99.3]\end{array}$ & $\begin{array}{l}2.05[0 \\
99.9]\end{array}$ \\
\hline & Interventi & Interventic & Interven & Interve & Interventic & Interventic & Interventio & Interv \\
\hline & Time & Time & Time & Time & Time & Time & Time & Time \\
\hline & $=5$ & $=5$ & $=5$ & $=5$ & $=5$ & $=5$ & $=5$ & $=5$ \\
\hline & days & & & & & & & \\
\hline & (None) & & & & & & & \\
\hline$(\mathrm{N}=1000)$ & $\beta=6 / 5$ & & & & & & & \\
\hline$(\mathrm{N}=1000)$ & $p=6 / 5$ & & & & & & & \\
\hline$(\mathrm{N}=1000)$ & $\delta=6 / 5$ & & & & & & & \\
\hline$(\mathrm{N}=1000)$ & $c=6 / 5$ & & & & & & & \\
\hline$(\mathrm{N}=1000)$ & $\begin{array}{l}\rho=2 / 5 \\
\delta=2 / 5\end{array}$ & & & & & & & \\
\hline & $\varsigma=2 / 5$ & & & & & & & \\
\hline$(\mathrm{N}=1000)$ & $\beta=2 / 5$ & & & & & & & \\
\hline & $p=2 / 5$ & & & & & & & \\
\hline & $\delta=2 / 5$ & & & & & & & \\
\hline$(\mathrm{N}=1000)$ & $\rho=3 / 5$ & & & & & & & \\
\hline$(\mathrm{N}=1000)$ & $\delta=3 / 5$ & & & & & & & \\
\hline
\end{tabular}




\begin{tabular}{|c|c|c|c|c|c|c|c|c|}
\hline & $\begin{array}{l}\text { Interventi } \\
\text { Time } \\
=5 \\
\text { days }\end{array}$ & $\begin{array}{l}\text { Interventic } \\
\text { Time } \\
=5 \\
\text { days }\end{array}$ & $\begin{array}{l}\text { Interventi } \\
\text { Time } \\
=5 \\
\text { days }\end{array}$ & $\begin{array}{l}\text { Interventi } \\
\text { Time } \\
=5 \\
\text { days }\end{array}$ & $\begin{array}{l}\text { Interventio } \\
\text { Time } \\
=5 \\
\text { days }\end{array}$ & $\begin{array}{l}\text { Interventic } \\
\text { Time } \\
=5 \\
\text { days }\end{array}$ & $\begin{array}{l}\text { Interventic } \\
\text { Time } \\
=5 \\
\text { days }\end{array}$ & $\begin{array}{l}\text { Interve } \\
\text { Time } \\
=5 \\
\text { days }\end{array}$ \\
\hline \multicolumn{9}{|l|}{ Detectable } \\
\hline \multicolumn{9}{|l|}{ Viral } \\
\hline \multicolumn{9}{|l|}{ Test, } \\
\hline \multicolumn{9}{|l|}{$\begin{array}{l}>100 \\
\text { copies } / \mathrm{mL}\end{array}$} \\
\hline Undetectable & $0(0 \%)$ & $0(0 \%)$ & $0(0 \%)$ & $0(0 \%)$ & $0(0 \%)$ & $0(0 \%)$ & $0(0 \%)$ & $0(0 \%)$ \\
\hline Detectable & $\begin{array}{l}1000 \\
(100 \%)\end{array}$ & $\begin{array}{l}1000 \\
(100 \%)\end{array}$ & $\begin{array}{l}1000 \\
(100 \%)\end{array}$ & $\begin{array}{l}1000 \\
(100 \%)\end{array}$ & $\begin{array}{l}1000 \\
(100 \%)\end{array}$ & $\begin{array}{l}1000 \\
(100 \%)\end{array}$ & $\begin{array}{l}1000 \\
(100 \%)\end{array}$ & $\begin{array}{l}1000 \\
(100 \%)\end{array}$ \\
\hline \multicolumn{9}{|l|}{ Modified } \\
\hline $\begin{array}{l}\text { Mean } \\
\text { (SD) }\end{array}$ & $14.2(0)$ & $\begin{array}{l}1.58 \\
(0.860)\end{array}$ & $\begin{array}{l}0.895 \\
(0)\end{array}$ & $\begin{array}{l}0.899 \\
(0)\end{array}$ & $\begin{array}{l}1.69 \\
(1.23)\end{array}$ & $\begin{array}{l}1.18 \\
(0.214)\end{array}$ & $\begin{array}{l}1.18 \\
(0.206)\end{array}$ & $\begin{array}{l}0.896 \\
(0)\end{array}$ \\
\hline $\begin{array}{l}\text { Median } \\
\text { [Min, Max] }\end{array}$ & $\begin{array}{l}14.2[14.2, \\
14.2]\end{array}$ & $\begin{array}{l}1.32[0.959, \\
13.5]\end{array}$ & $\begin{array}{l}0.895 \\
{[0.895,} \\
0.895]\end{array}$ & $\begin{array}{l}0.899 \\
{[0.899,} \\
0.899]\end{array}$ & $\begin{array}{l}1.32[0.956, \\
13.3]\end{array}$ & $\begin{array}{l}1.11[0.925, \\
2.25]\end{array}$ & $\begin{array}{l}1.11[0.930, \\
2.22]\end{array}$ & $\begin{array}{l}0.896 \\
{[0.896,} \\
0.896]\end{array}$ \\
\hline \multicolumn{9}{|l|}{$\begin{array}{l}\text { Shed- } \\
\text { ding, } \\
\text { days }\end{array}$} \\
\hline $\begin{array}{l}\text { Mean } \\
(\mathrm{SD})\end{array}$ & $\begin{array}{l}10.5 \\
(5.32)\end{array}$ & $\begin{array}{l}11.1 \\
(7.65)\end{array}$ & $\begin{array}{l}8.57 \\
(5.56)\end{array}$ & $\begin{array}{l}4.79 \\
(1.00)\end{array}$ & $\begin{array}{l}8.05 \\
(5.27)\end{array}$ & $\begin{array}{l}6.20 \\
(3.08)\end{array}$ & $\begin{array}{l}6.83 \\
(4.69)\end{array}$ & $\begin{array}{l}5.37 \\
(1.76)\end{array}$ \\
\hline $\begin{array}{l}\text { Median } \\
{[\text { Min, Max] }}\end{array}$ & $\begin{array}{l}9.00[3.34, \\
44.0]\end{array}$ & $\begin{array}{l}9.00[3.40, \\
53.8]\end{array}$ & $\begin{array}{l}7.17[3.46, \\
50.2]\end{array}$ & $\begin{array}{l}4.49[3.40, \\
16.0]\end{array}$ & $\begin{array}{l}6.94[3.40, \\
53.4]\end{array}$ & $\begin{array}{l}5.37[3.34, \\
38.0]\end{array}$ & $\begin{array}{l}5.94[3.46, \\
52.8]\end{array}$ & $\begin{array}{l}4.94[3 . \\
26.2]\end{array}$ \\
\hline \multicolumn{9}{|l|}{ Target } \\
\hline \multicolumn{9}{|l|}{$\begin{array}{l}\text { Re- } \\
\text { main- } \\
\text { ing, } \\
\%\end{array}$} \\
\hline $\begin{array}{l}\text { Mean } \\
\text { (SD) }\end{array}$ & $0(0)$ & $\begin{array}{l}1.99 \\
(9.75)\end{array}$ & $\begin{array}{l}2.13 \\
(10.0)\end{array}$ & $\begin{array}{l}2.16 \\
(9.54)\end{array}$ & $\begin{array}{l}1.84 \\
(8.74)\end{array}$ & $\begin{array}{l}2.38 \\
(10.6)\end{array}$ & $\begin{array}{l}2.42 \\
(11.4)\end{array}$ & $\begin{array}{l}1.53 \\
(8.44)\end{array}$ \\
\hline $\begin{array}{l}\text { Median } \\
\text { [Min, Max] }\end{array}$ & $0[0,0]$ & $0[0,88.8]$ & $0[0,89.6]$ & $0[0,92.4]$ & $0[0,93.9]$ & $0[0,98.2]$ & $0[0,95.0]$ & $0[0,95$ \\
\hline
\end{tabular}

\begin{tabular}{|c|c|c|c|c|c|c|c|c|}
\hline & $\begin{array}{l}\text { Interve } \\
\text { Time } \\
=10 \\
\text { days }\end{array}$ & $\begin{array}{l}\text { Interv } \\
\text { Time } \\
=10 \\
\text { days }\end{array}$ & $\begin{array}{l}\text { Inters } \\
\text { Time } \\
=10 \\
\text { days }\end{array}$ & $\begin{array}{l}\text { Inter } \\
\text { Time } \\
=10 \\
\text { days }\end{array}$ & $\begin{array}{l}\text { Inter } \\
\text { Time } \\
=10 \\
\text { days }\end{array}$ & $\begin{array}{l}\text { Interv } \\
\text { Time } \\
=10 \\
\text { days }\end{array}$ & $\begin{array}{l}\text { Interv } \\
\text { Time } \\
=10 \\
\text { days }\end{array}$ & $\begin{array}{l}\text { Interv } \\
\text { Time } \\
=10 \\
\text { days }\end{array}$ \\
\hline $\begin{array}{l}(\mathrm{N}=1000) \\
(\mathrm{N}=1000) \\
(\mathrm{N}=1000) \\
(\mathrm{N}=1000)\end{array}$ & $\begin{array}{l}\text { (None) } \\
\beta=6 / 5 \\
\rho=6 / 5 \\
\delta=6 / 5 \\
c=6 / 5\end{array}$ & & & & & & & \\
\hline
\end{tabular}




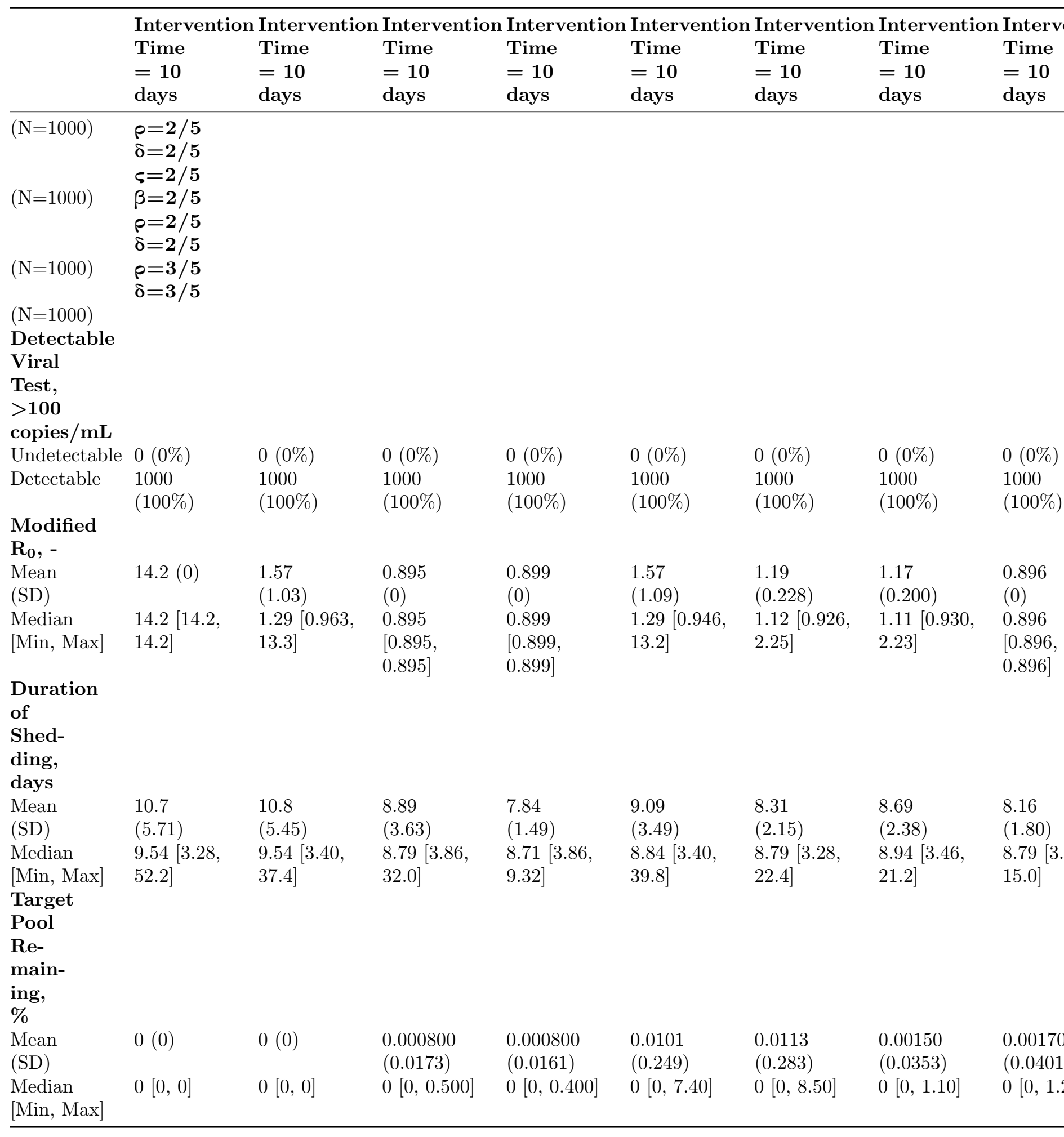

Figures

Figure 1 Display of the SARS-CoV-2 viral load data pooled from 13 studies 


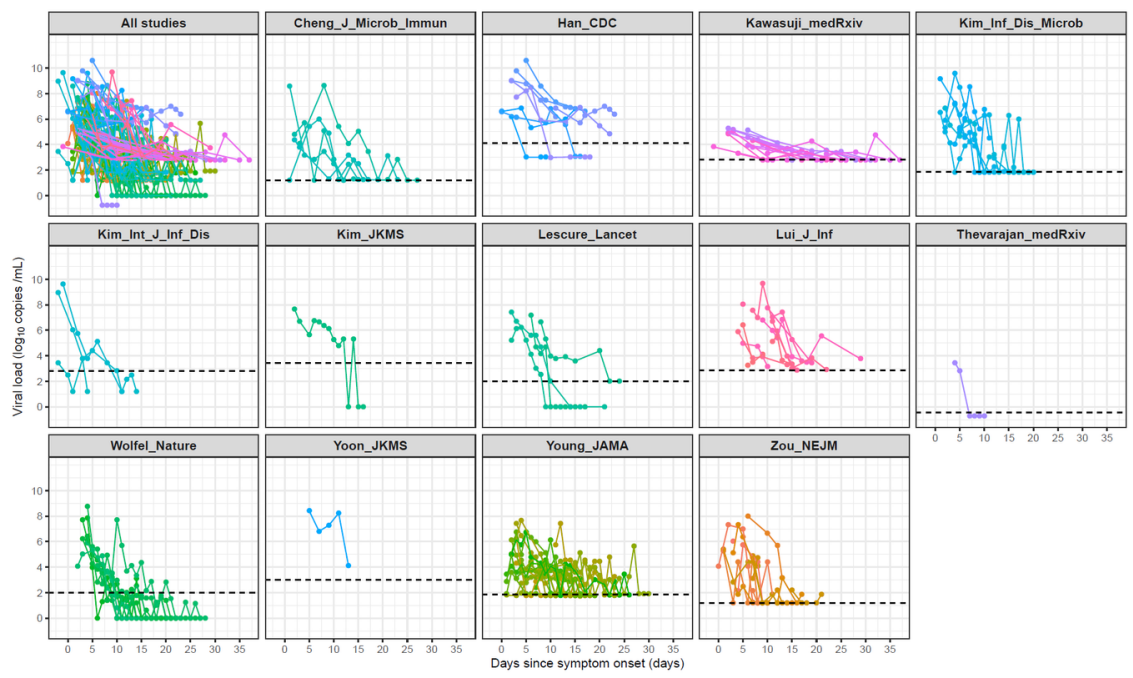

SARS-CoV-2 viral load versus time data from 13 published studies ${ }^{22-34}$. Lines represent the data for each individual subject. Horizontal dashed lines show the lower limit of quantitation from each study.

Figure 2 Schematic of the target cell-limited model of viral infection

\section{Hosted file}

image2.emf available at https://authorea.com/users/355077/articles/478455-using-in-silicoviral-kinetic-models-to-guide-therapeutic-strategies-during-a-pandemic-an-example-insars-cov-2

Figure 3 Visual Predictive Check of the target cell-limited model for SARS-CoV-2 


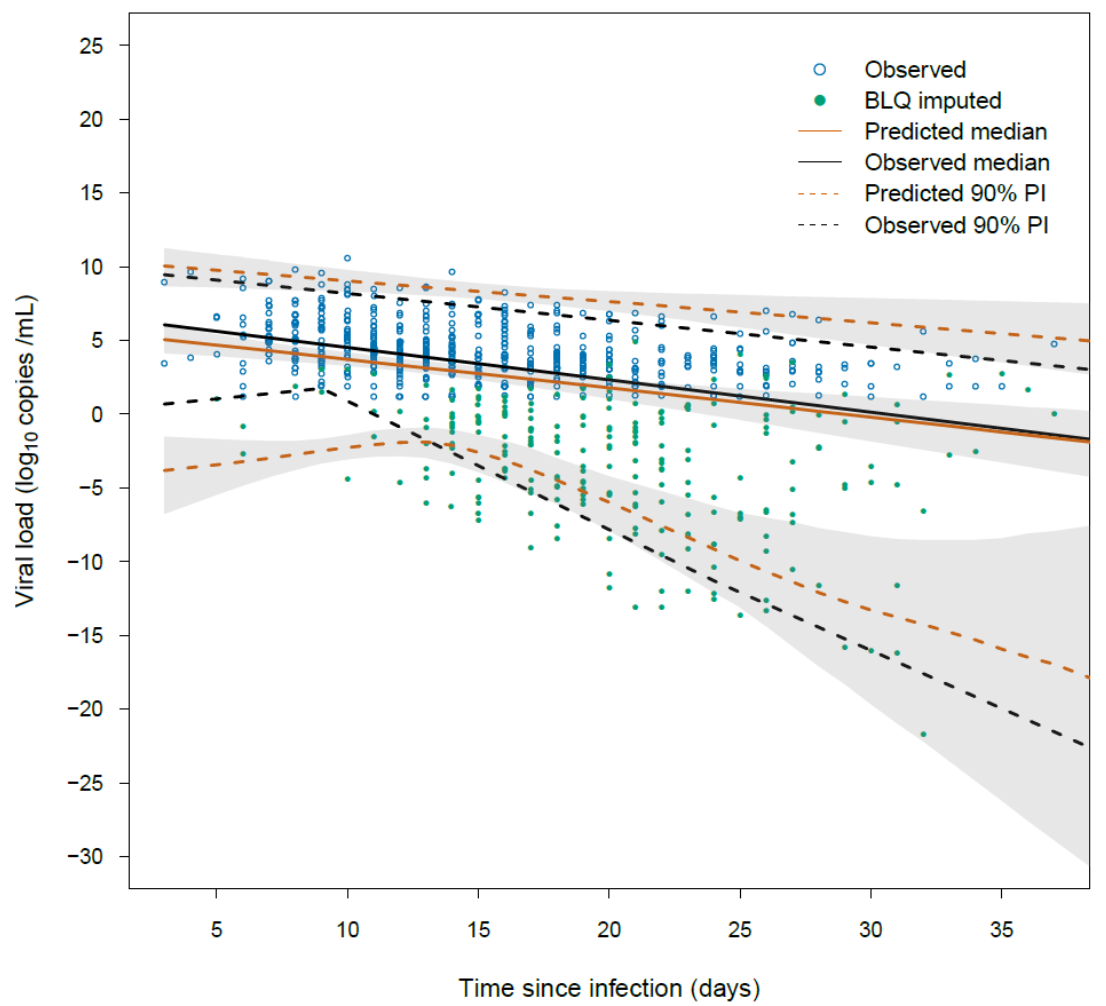

Visual predictive check for SARS-CoV-2 viral kinetics in symptomatic infected subjects. Orange lines show model-predicted percentiles ( $\mathrm{N}=500$ replicate datasets) with black lines representing corresponding observed percentiles. Censored data are shown in green. The $90^{\text {th }}$ prediction interval is illustrated using dashed lines.

Figure 4 Effect of monotherapy and combination interventions on detectable viral load

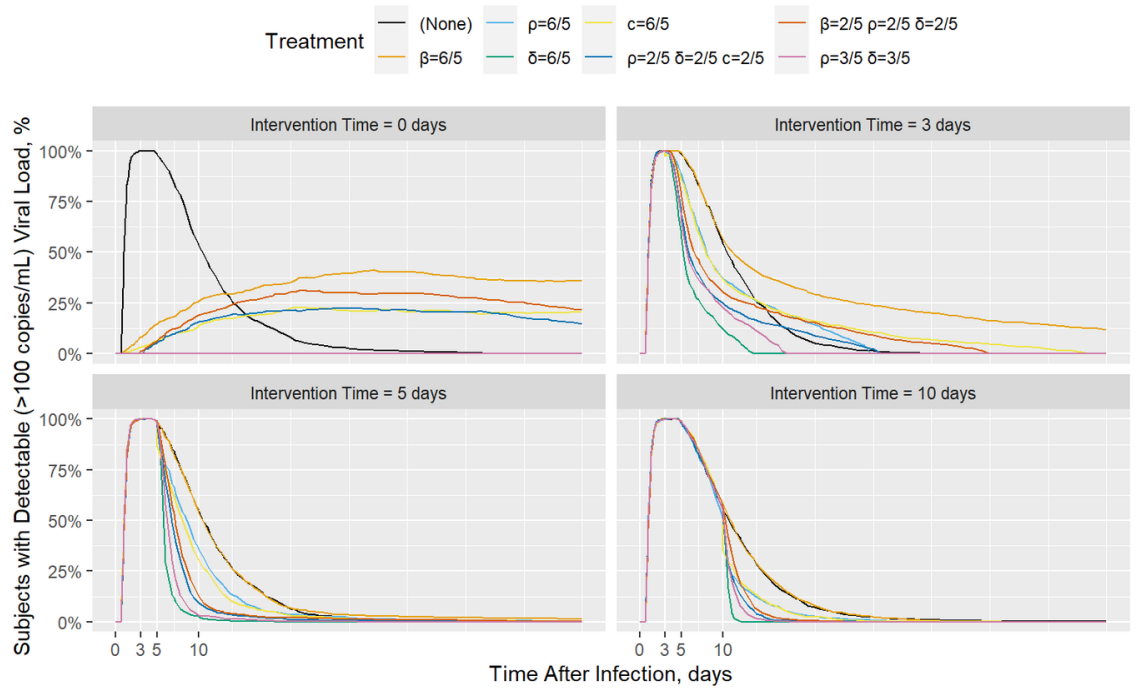

Percent of subjects with detectable (>100 copies/mL) viral load. 
Figure 5 Effect of monotherapy and combination interventions on SARS-CoV-2 viral kinetics

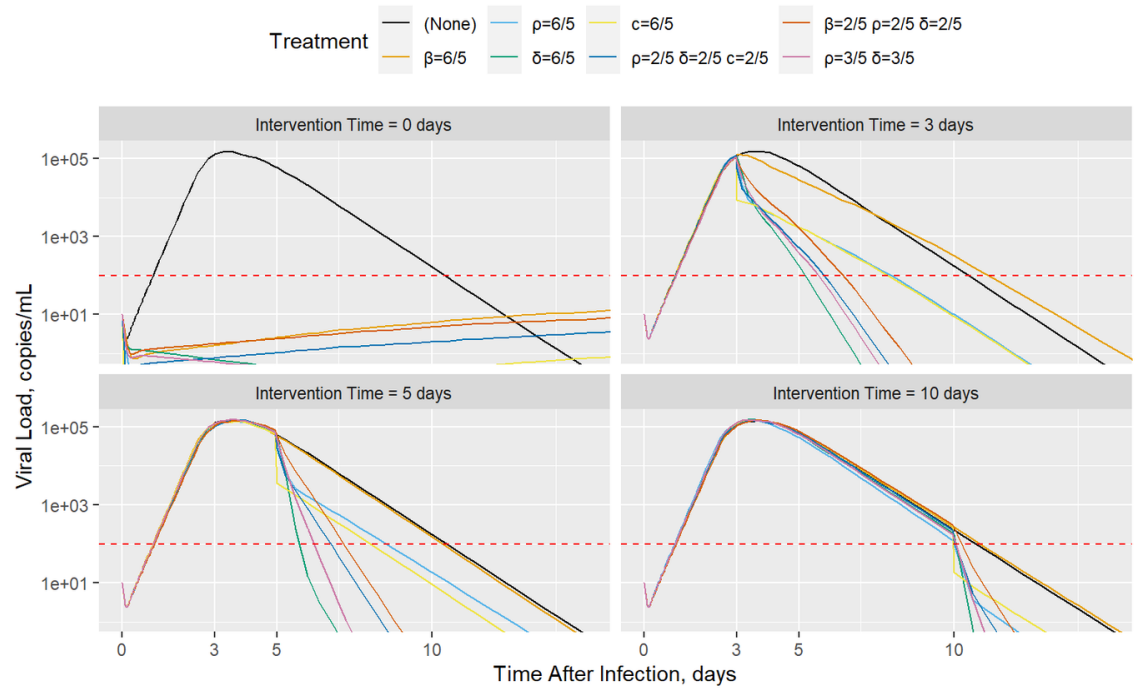

Red, dashed line is the assumed LLOQ of 100 copies/mL.

Median viral load by treatment and intervention time.

Figure 6 Effect of interventions on the remaining target epithelial cell pool population

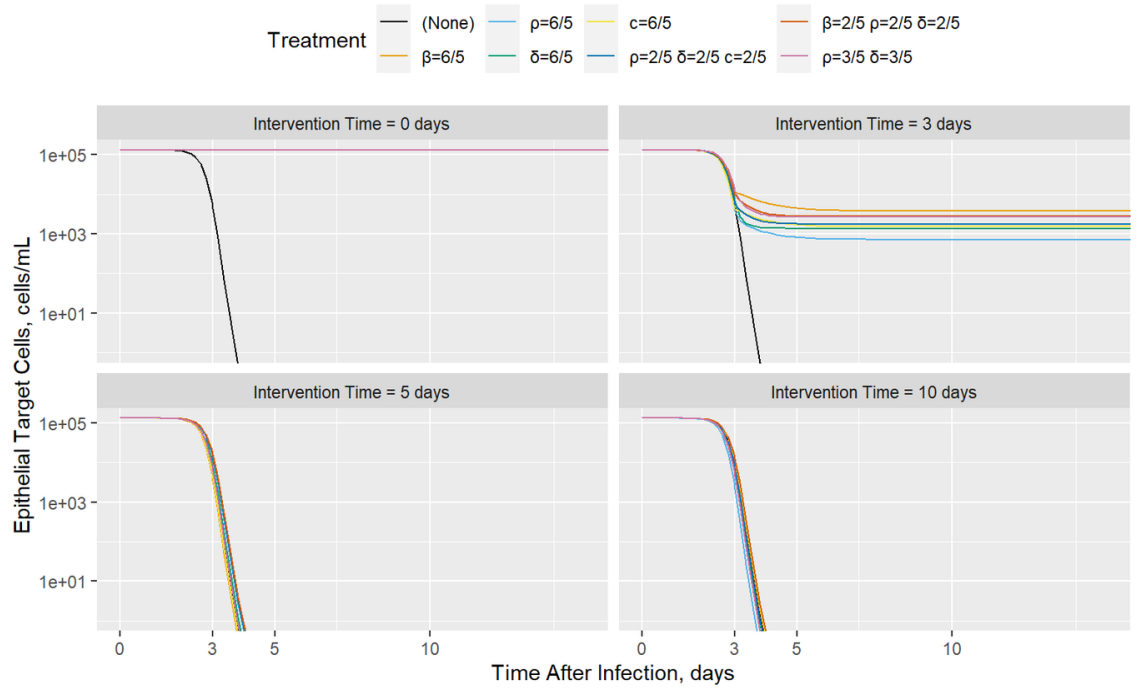

Median target cell population by treatment and intervention time.

\section{Supplemental material}

Supplemental Table 1 Viral load exposures summarized by disease severity

\begin{tabular}{lllll}
\hline Infection severity & $\mathrm{N}$ & $\mathrm{AUC}\left(\log _{10}\right.$ copies $\left.\times \mathrm{d} / \mathrm{mL}\right)$ & $\mathrm{VL}_{\max }\left(\log _{10}\right.$ copies $\left./ \mathrm{mL}\right)$ & $\mathrm{T}_{\max }($ days $)$ \\
\hline & Median [range] & Median [range] & Median [range]
\end{tabular}




\begin{tabular}{lllll}
\hline Infection severity & $\mathrm{N}$ & $\mathrm{AUC}\left(\log _{10}\right.$ copies $\left.\times \mathrm{d} / \mathrm{mL}\right)$ & $\mathrm{VL}_{\max }\left(\log _{10}\right.$ copies $\left./ \mathrm{mL}\right)$ & $\mathrm{T}_{\max }($ days $)$ \\
\hline Mild & 38 & $78.9[9.26-2050]$ & $7.05[3.69-10.6]$ & $4.00[-2.00-21.0]$ \\
Mild-to-Moderate & 14 & $39.1[25.8-1710]$ & $4.74[1.19-7.32]$ & $4.74[1.01-15.0]$ \\
Moderate & 1 & $217[217-217]$ & $7.67[7.67-7.67]$ & $2.00[2.00-2.00]$ \\
Severe & 10 & $321[65.1-20700]$ & $5.62[3.59-7.98]$ & $5.00[1.86-8.00]$ \\
Uncomplicated & 13 & $95.3[34.7-504]$ & $5.63[3.69-7.43]$ & $7.00[2.00-27.0]$ \\
Unknown & 29 & $144[37.1-661]$ & $4.92[2.78-9.66]$ & $5.00[-1.00-32.0]$ \\
\hline
\end{tabular}

Abbreviations: AUC, area under the viral load curve; $\mathrm{T}_{\max }$, time of peak viral load; $\mathrm{VL}_{\max }$, peak viral load.

Supplemental Figure 1 Distribution of viral load exposures by disease severity
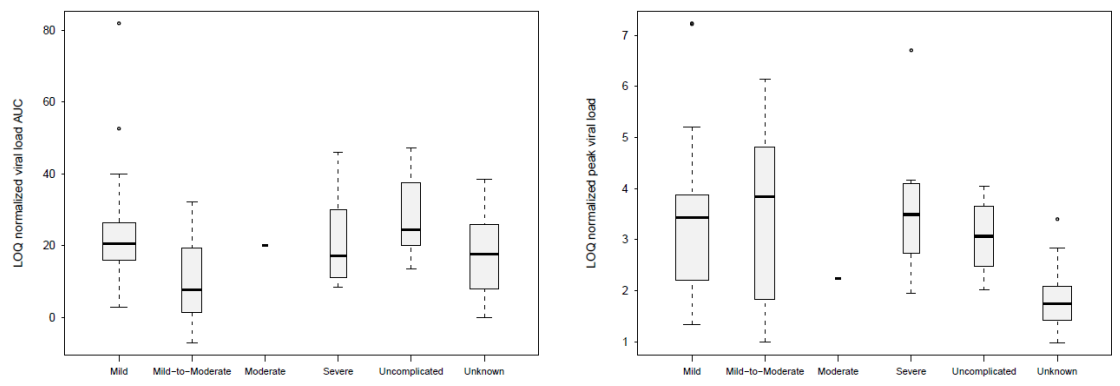

No apparent trend in viral exposures by infection severity in the current analysis population.

Supplemental Figure 2 Impact of infection severity on estimated between-subject variability

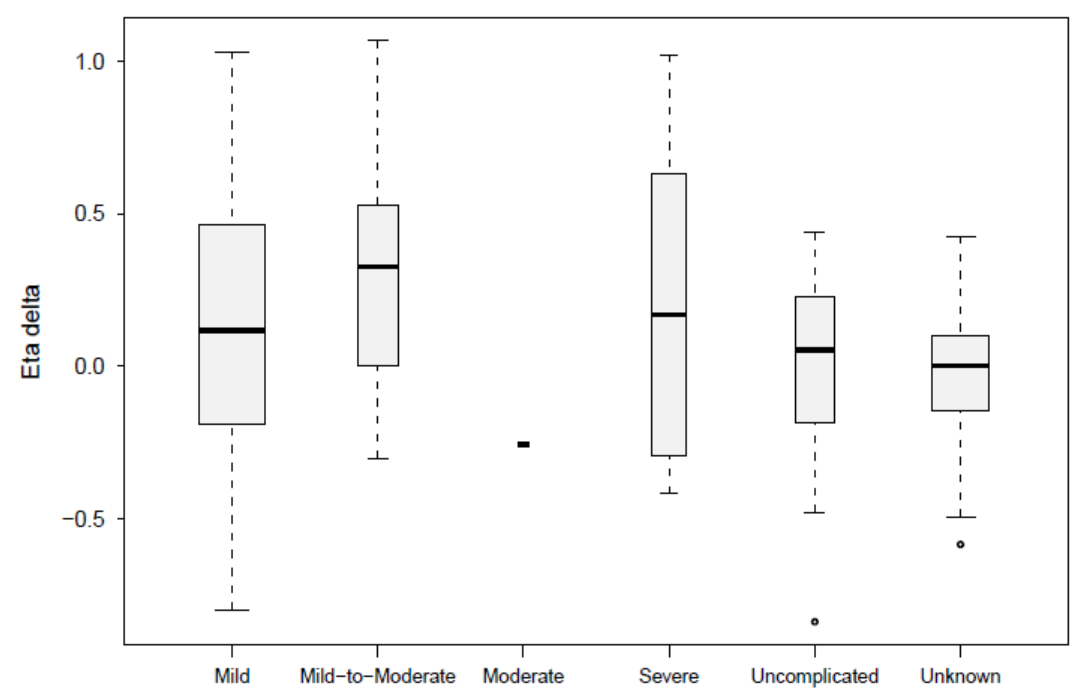

